\begin{tabular}{l|r|r}
\hline Jurnal Penelitian Kesmasy & Vol. 2 No. 1 & Edition: May-October 2019 \\
\hline \multirow{2}{*}{ Received: 15 October 2019} & $\frac{\text { http://ejournal.delihusada.ac.id/index.php/JPKSY }}{\text { Accepted: } 25 \text { October } 2019}$ \\
\cline { 2 - 3 } & Revised: 12 October 2019 & \\
\hline
\end{tabular}

\title{
ANALISA PENGETAHUAN SIKAP DAN PERILAKU PENGANGKUT SAMPAH TERHADAP ASPEK KESELAMATAN KESEHATAN KERJA DALAM PENGOLAHAN SAMPAH
}

\author{
Marzuki Samion \\ Universitas Islam Sumatera Utara, Jln. STM No. 77 Medan \\ email: marzuki.samion@fk.uisu.ac.id
}

\begin{abstract}
The purpose of this research is to knowing correlation of knowledge, attitute and practice of garbage attendant laborers of aspects of occupational health and safety against waste processing at TPS in Pasir Pangaraian Rokan Hulu Riau. This research uses analytical method with cross sectional design. The population in this study were all Garbage attendant Laborers at TPS in Pasir Pangaraian amounted to 64 people with total sampling method. Data analysis using chi square test indicated that there is correlation between knowledge with occupational health and safety at TPS in Pasir Pengarain. Value $p=0.026<0,05$ indicate that there is correlation between attitute with occupational health and safety at TPS in Pasir Pengarain. The value of $p=0.034<0.05$ indicates that there is correlation between practice with occupational health and safety in TPS in Pasir Pengarain Conclusion: There is a relationship of Attitude, Knowledge and Practice with occupational health and safety at TPS in Pasir Pengarain.
\end{abstract}

Keywords: Garbage workers, attitude, practice, occupational health safety

\section{PENDAhUluan}

Sampah erat kaitannya dengan kesehatan masyarakat, karena dari sampah-sampah tersebut hidup berbagai mikroorganisme yang merupakan penyebab penyakit. Pengelolaan sampah yang kurang baik dapat memberikan pengaruh negatif bagi kesehatan. Penyakit yang erat kaitannya dengan sampah sangat luas seperti penyakit menular, tidak menular dan lain-lain. Penyebabnya dapat berupa bakteri, jamur, cacing dan zat kimia. Salah satu penyakit menular yang diakibatkan oleh sampah dapat terinfeksi melalui kulit. Bakteri, virus dan jamur yang menginfeksi kulit sangat umum terjadi dan dapat merusak kulit (Wijayanti, 2015).

Salah satu bentuk keseriusan negara dalam menghadapi permasalahan lingkungan, terutama mengenai sampah dapat dinilai dari lahirnya Undang-Undang Nomor 23 Tahun 1997 tentang Pengelolaan Lingkungan Hidup; Pasal 12 ayat 1 , yang ditindak lanjuti dengan lahirnya Undang-Undang Nomor 18 Tahun 2008 tentang pengelolaan sampah, dimana di dalamnya diatur mengenai tugas dan wewenang pengelolaan sampah rumah tangga, sejenis rumah tangga dan spesifik (Sari, 2016a).

Petugas sampah dalam hal ini pengangkut sampah merupakan kelompok yang berkaitan erat dengan sampah dan rentan terhadap penyakit kulit akibat kontaminasi dari sampahsampah tersebut dan maka dari itu merupakan salah satu kelompok yang seharusnya menggunakan alat pelindung diri untuk melindungi kesehatan dan keselamatannya dalam bekerja. Pengetahuan, sikap dan tindakan merupakan tingkatan yang dilalui untuk menentukan individu memiliki perilaku penggunaan alat pelindung diri yang baik (Wijayanti, 2015).

Rokan hulu merupakan salah satu kota yang sedang mengalami perkembangan dan pembangunan. Data dari sensus penduduk yang dilakukan Badan Pusat Statistik tahun 2016, menyebutkan jumlah penduduk yang bermukim di Rokan Hulu adalah 616.466 jiwa dari 6.500.971 jiwa total penduduk Riau, dengan jumlah masyarakat yang terus meningkat serta beragam aktivitas menyebabkan volume dan jenis sampah yang dihasilkan setiap hari semakin bertambah dan beragam, namun keadaan tersebut tidak diikuti 


\begin{tabular}{l|r|r}
\hline Jurnal Penelitian Kesmasy & Vol. 2 No. 1 & Edition: May - October 2019 \\
\hline \multirow{2}{*}{ Received: 15 October 2019} & http://ejournal.delihusada.ac.id/index.php/JPKSY & Accepted: 25 October 2019 \\
\cline { 2 - 3 } & Revised: 12 October 2019 & \\
\hline
\end{tabular}

dengan perbaikan dan penyediaan sarana dan prasarana pengelolaan sampah yang memadai serta masih rendahnya pemahaman masyarakat mengenai pentingnya hidup bersih (Sari, 2016a; BPS, 2016).

Pasir Pengaraian kabupaten Rokan Hulu memiliki satu buah tempat pembuangan akhir dengan menerapkan sistem open dumpling yang berlokasi di desa Tanjung Belit, kecamatan Rambah dan 8 unit tempat pembuangan sementara yang berlokasi 6 unit di Pasar Senin, 1 unit di DPRD dan 1 unit di desa Kampung Bukit. Sarana dan prasarana pengelolaan sampah di Pasir Pengaraian yang dimiliki saat ini tidak sebanding dengan melimpahnya produksi sampah yang dihasilkan oleh masyarakat sehingga menyebabkan tempat pembuangan sampah sementara liar bermunculan dimana-mana, sehingga sangat berpotensi menyebabkan terjadinya pencemaran lingkungan di sekitar tempat pembuangan sementara (Rahmi, 2013).

Keselamatan dan kesehatan kerja difilosofikan sebagai suatu pemikiran dan upaya untuk menjamin keutuhan dan kesempurnaan baik jasmani maupun rohani tenaga kerja pada khususnya dan manusia pada umumnya, hasil karya dan budayanya menuju masyarakat makmur dan sejahtera. Sedangkan pengertian secara keilmuan adalah suatu ilmu pengetahuan dan penerapannya dalam usaha mencegah kemungkinan terjadinya kecelakaan dan penyakit akibat kerja (Redjeki, 2016).

Perlindungan keselamatan pekerja melalui upaya teknis pengamanan tempat, mesin, peralatan dan lingkungan kerja wajib diutamakan. Namun Suma'mur (2013) menyatakan bahwa kadang-kadang risiko terjadinyan kecelakaan masih belum sepenuhnya dapat dikendalikan, sehingga digunakan alat pelindung diri (alat proteksi diri/personal protective device). Jadi penggunaan alat pelindung diri adalah alternatif terakhir yaitu kelengkapan dari segenap upaya teknis pencegahan kecelakaan. Alat pelindung diri harus memenuhi persyaratan: enak (nyaman) dipakai; tidak mengganggu pelaksanaan pekerjaan; dan memberikan perlindungan efektif terhadap macam bahaya yang dihadapi.

Pengetahuan adalah hasil tahu dan ini terjadi setelah orang melakukan pengindraan terhadap suatu objek tertentu. Pengindraan terjadi melalui manusia, yakni: indra penglihatan, pendengaran, penciuman, rasa, dan raba. Sebagian besar pengetahuan manusia diperoleh melalui mata dan telinga (Notoatmodjo, 2011).

Sikap merupakan reaksi atau respon seseorang yang masih tertutup terhadap suatu stimulus atau objek. Sikap secara nyata menunjukkan konotasi adanya kesesuaian reaksi terhadap stimulus tertentu. Dalam kehidupan sehari-hari merupakan reaksi yang bersifat emosional terhadap stimulus sosial (Notoatmodjo, 2011).

Dari aspek biologis perilaku adalah suatu kegiatan atau aktivitas organisme atau makhluk hidup yang bersangkutan. Oleh sebab itu dari segi biologis, semua makhluk hidup mulai dari binatang sampai dengan manusia, mempunyai aktivitas masing-masing. Manusia sebagai salah satu makhluk hidup mempunyai bentengan kegiatan yang sangat luas, sepanjang kegiatan yang dilakukan manusia tersebut antara lain: berjalan, berbicara, bekerja, menulis, membaca, dan berpikir (Notoatmodjo, 2010).

Pekerja pengangkut sampah umumnya rentan terhadap penyakit kulit akibat kontaminasi dari sampah-sampah tersebut sehingga perlunya keselamatan kesehatan kerja pada petugas pengangkut sampah. Adapun tujuan penelitian ini adalah untuk mengetahui hubungan pengetahuan, sikap, dan perilaku pengangkut sampah terhadap aspek keselamatan kesehatan kerja dalam pengolahan sampah ditempat pembuangan sementara di Pasir Pengaraian, Rokan Hulu, Riau.

\section{METODE PENELITIAN}

Jenis penelitian ini merupakan penelitian analitik obsevasional dengan metode cross sectional. Waktu penelitian ini dimulai pada bulan Mei 2018 sampai Januari 2019. Penelitian ini dilakukan di tempat pembuangan sampah sementara di Pasir Pengaraian, Rokan Hulu, Riau. Sampel pada penelitian ini diambil menggunakan total sampling, sebagaimana pendapat Notoatmodjo (2012) bahwa populasi kurang dari 100 orang dapat diambil sampel keseluruhannya, yaitu 31 orang.

Analisis data dilakukan dengan analisis data univariat dan dilanjukan dengan analisis data bivariat. Analisa Univariat yang dilakukan terhadap tiap variabel dari hasil penelitian. Pada umumnya dalam analisis ini hanya menghasilkan distribusi dan persentase 


\begin{tabular}{l|r|r}
\hline Jurnal Penelitian Kesmasy & Vol. 2 No. 1 & Edition: May-October 2019 \\
\hline \multirow{2}{*}{ Received: 15 October 2019} & $\frac{\text { http://ejournal.delihusada.ac.id/index.php/JPKSY }}{\text { Accepted: } 25 \text { October } 2019}$ \\
\cline { 2 - 3 } & Revised: 12 October 2019 & \\
\hline
\end{tabular}

dari tiap variabel, sehingga diketahui variasi dari masing-masing variabel. Analisa Bivariat dilakukan terhadap dua variable yang diduga berhubungan atau berkolerasi. Analisa data ini dilakukan dengan menggunakan program komputer ( $p \leq 0,05)$.

\section{HASIL PENELITIAN}

Tempat penelitian dilakukan di PasirPengaraian kabupaten Rokan Hulu Provinsi Riau yang memiliki 8 TPS yang berlokasi 6 unit di Pasar Senin, 1 unit di DPRD dan 1 unit di desa Kampong Bukit. Penelitian ini telah dilakukan pada bulan Desember 2018 terhadap petugas pengangkut sampah. Jumlah responden yamg menjadi sampel adalah 31 orang. Pada saat dilakukannya penelitian pekerja pengangkut sampah telah selesai melakukan pekerjaannya.

Berdasarkan variabel umur (tabel 3.1) jumlah pengamatan dengan umur 15-24 tahun sebanyak $6.5 \%$, pengamatan dengan umur 25 44 tahun sebanyak $61.3 \%$ dan pengamatan dengan umur lebih dari 45 tahun sebanyak $32.3 \%$.

Tabel 3.1 Distribusi Frekuensi dan presentase Berdasarkan Umur

\begin{tabular}{ccc}
\hline Umur & f & \% \\
\hline 15-24 tahun & 2 & 6.5 \\
25-44 tahun & 19 & 61.3 \\
$>45$ tahun & 10 & 32.3 \\
Total & 31 & 100 \\
\hline
\end{tabular}

Berdasarkan variabel keselamatan kesehatan kerja (Tabel 3.2) jumlah pengamatan dengan keselamatan kesehatan kerja dengan kategori kurang sebanyak $19.4 \%$ dan kategori baik sebanyak $80.6 \%$.

Tabel 3.2 Distribusi Frekuensi dan presentase Berdasarkan Kesehatan Keselamatan kerja

\begin{tabular}{ccc}
\hline K3 & f & \% \\
\hline Kurang & 6 & $19.4 \%$ \\
Baik & 25 & $80.6 \%$ \\
\hline
\end{tabular}

Hasil penelitian menunjukkan bahwa pengetahuan, sikap dan perilaku yang ditunjukkan pekerja pengangkut sampah terhadap keselamatan dan kesehatan kerja sudah baik, dimana pada variabel pengetahuan, jumlah responden dengan pengetahuan kurang sebanyak $12.9 \%$ dan responden dengan pengetahuan baik sebanyak $87.1 \%$. Pada variabel sikap, jumlah responden dengan sikap kurang sebanyak $25.8 \%$ dan responden dengan sikap baik sebanyak $74.2 \%$. Pada variabel perilaku, jumlah responden dengan perilaku kurang sebanyak $61.3 \%$ dan responden dengan perilaku baik sebanyak 67.7\%. Lihat tabel 3.3 .

Tabel 3.3 Distribusi Frekuensi dan presentase Berdasarkan pengetahuan, Sikap dan Perilaku

\begin{tabular}{|l|l|c|c|}
\hline \multirow{2}{*}{ Aspek } & \multirow{2}{*}{ Kategori } & \multicolumn{2}{|c|}{ Distribusi } \\
\cline { 3 - 4 } & & f & \% \\
\hline \multirow{2}{*}{ Pengetahuan } & Kurang & 4 & 12,9 \\
\cline { 2 - 4 } & Baik & 27 & 87,1 \\
\hline \multirow{2}{*}{ Sikap } & Kurang & 8 & 25,8 \\
\cline { 2 - 4 } & Baik & 23 & 74,2 \\
\hline Perilaku & Kurang & 10 & 32,3 \\
\cline { 2 - 4 } & Baik & 21 & 67,7 \\
\hline
\end{tabular}

Adapun hasil pengamatan terhadap hubungan antara keselamatan dan Kesehatan kerja terhadap pengetahuan, sikap dan perilaku pekerja pengangkut sampah ditunjukkan oleh tabel berikut.

Tabel 3.4 Hubungan antara Keselamatan Kesehatan kerja dengan Pengetahuan

\begin{tabular}{ccccc}
\hline \multirow{2}{*}{$\begin{array}{c}\text { Pengeta } \\
\text { huan }\end{array}$} & \multicolumn{2}{c}{ K3 } & \multirow{2}{*}{ Total } & $\begin{array}{c}\text { P- } \\
\text { Value }\end{array}$ \\
\cline { 2 - 3 } Kurang & Kurang & Baik & & \\
& 2 & 2 & 4 & \\
Baik & $(50 \%)$ & $(50 \%)$ & $(100 \%)$ & \\
& 4 & 23 & 27 & \multirow{2}{*}{0.04} \\
\hline Total & $(14.8 \%)$ & $(85.2 \%)$ & $(100 \%)$ & \\
& 6 & 25 & 31 & \\
\hline
\end{tabular}

Tabel diatas menunjukkan adanya hubungan pengetahuan responden dengan keselamatan kesehatan kerja yaitu dengan nilai $\mathrm{p}$ sebesar $0.04<0.05$.

Tabel 3.5 Hubungan antara Keselamatan Kerja dengan Sikap

\begin{tabular}{ccccc}
\hline \multirow{2}{*}{ Sikap } & \multicolumn{1}{l}{ K3 } & & Total & $\begin{array}{c}\text { P- } \\
\text { Value }\end{array}$ \\
\cline { 2 - 3 } & Kurang & Baik & & \\
\hline Kurang & 4 & 4 & 8 & \\
Baik & $(50 \%)$ & $(50 \%)$ & $(100 \%)$ & \\
& 2 & 21 & 23 & \multirow{2}{*}{0.026} \\
\hline Total & $(8.7 \%)$ & $(91.3 \%)$ & $(100 \%)$ & \\
& 6 & 25 & 31 & \\
\hline
\end{tabular}

Tabel 3.5. di atas menunjukkan bahwa ada hubungan sikap responden dengan keselamatan kesehatan kerja yaitu dengan nilai P sebesar $0.026<0.05$. 


\begin{tabular}{|l|r|r}
\hline \multirow{2}{*}{ Jurnal Penelitian Kesmasy } & Vol. 2 No. 1 & Edition: May-October 2019 \\
\hline \multirow{2}{*}{ Received: 15 October 2019} & http://ejournal.delihusada.ac.id/index.php/JPKSY & Accepted: 25 October 2019 \\
\cline { 2 - 3 } & Revised: 12 October 2019 & \\
\hline
\end{tabular}

Tabel 3.6 Hubungan antara Keselamatan Kesehatan Kerja dengan Perilaku

\begin{tabular}{ccccc}
\hline \multirow{2}{*}{$\begin{array}{c}\text { Peri- } \\
\text { laku }\end{array}$} & \multicolumn{2}{c}{ K3 } & Total & $\begin{array}{c}\text { P- } \\
\text { Value }\end{array}$ \\
\cline { 2 - 3 } Kurang & Kurang & Baik & & \\
& $(10 \%)$ & $(90 \%)$ & $(100 \%)$ & \\
Baik & 5 & 16 & 21 & \\
& $(23.8 \%)$ & $(76.2 \%)$ & $(100.0 \%)$ & 0.034 \\
\hline Total & 6 & 25 & 31 & \\
& $(19.4 \%)$ & $(80.6 \%)$ & $(100 \%)$ & \\
\cline { 2 - 3 } & & & &
\end{tabular}

Berdasarkan tabel 3.6 di atas bahwa ada hubungan perilaku dengan keselamatan kesehatan kerja yaitu dengan nilai $\mathrm{P}$ sebesar $0.034<0.005$.

Berdasarkan data statistik menunjukkan untuk umur responden didapatkan hasil bahwa sebagian besar petugas pengangkut sampah memiliki umur antara 25-44 tahun yaitu sebanyak 61.3\%. Menurut Irwanto (2002), umur mendapatkan perhatian khusus karena akan mempengaruhi kondisi fisik, mental, kemauan kerja, dan tanggung jawab seseorang. Dalam teori perkembangan faktor kerja maupun umur dapat digolongkan menjadi dewasa awal umur 18-40 tahun dan dewasa lanjut umur 41-60 tahun. Umur pekerja dewasa awal diyakini dapat membangun kesehatannya dengan cara mencegah suatu penyakit atau menanggulangi gangguan penyakitnya. Untuk melakukan kegiatan tersebut, pekerja muda akan lebih disiplin menjaga kesehatannya, sedangkan pada umur dewasa lanjut akan mengalami kebebasan dalam kehidupan bersosialisasi, kewajiban pekerja dewasa lanjut akan berkurang terhadap kehidupan bersama (Tombili, 2015).

Berdasarkan data statistik menunjukkan untuk pengetahuan responden didapatkan hasil bahwa sebagian besar petugas pengangkut sampah memiliki pengetahuan baik yaitu sebanyak $87.1 \%$ dan hanya $12.9 \%$ yang memiliki pengetahuan kurang.

Tinggi rendahnya pengetahuan seseorang juga dipengaruhi oleh beberapa faktor, sebagaimana yang dijelaskan dalam Notoatmodjo bahwa ada faktor-faktor yang bisa mempengaruhi tingkat pengetahuan seseorang seperti faktor Usia, Pendidikan, Media massa, sosial ekonomi, hubungan sosial dan pengalaman pribadi seseorang. Pada saat ini media massa sebagai sarana komunikasi, berbagai media masa seperti televisi, surat kabar, radio, internet sekrang memberi pengaruh cukup besar dalam pembentukan opini dan kepercayaan seseorang dalam membawa pesan-pesan yang berisi sugesti yang dapat mengarah pada opini yang kemudian dapat menjadi landasan terbentuknya sikap, serta melalui media massa ini terutama internet memberikan kemudahan bagi kita dalam mengakses informasi-informasi yang bisa menambah pengetahuan. Selain itu jika ditinjau dari segi usia maka semakin bertambah usia seseorang maka semakin berkembang pula daya dan pola pikir seseorang sehingga pengetahuan yang diperoleh semakin baik (Notoatmodjo, 2011).

Penelitian ini sejalan dengan penelitian yang dilakukan oleh Wijayanti (2015) yang menyatakan bahwa sebagian besar petugas sampah memiliki tingkat pengetahuan yang baik mengenai APD sebanyak $89,6 \%$ dan hanya $10.4 \%$ yang memiliki tingkat pengetahuan sedang serta tidak didapatkan petugas sampah yang memiliki tingkat pengetahuan kurang.

Berdasarkan data statistik menunjukkan untuk sikap responden didapatkan hasil bahwa sebagian besar petugas pengangkut sampah memiliki sikap baik yaitu sebanyak $74.2 \%$ dan hanya $25.8 \%$ yang memiliki sikap kurang. Sikap merupakan kesiapan atau kesediaan untuk bertindak, namun belum berupa tindakan melainkan predisposisi tindakan suatu perilaku, dengan kata lain sikap itu masih merupakan reaksi tertutup. Sikap seseorang baik ataupun kurang dipengaruhi oleh beberapa faktor, diantaranya pengalaman pribadi, orang lain, kebudayaan, emosional dan lingkungan. Menurut Allport ada kompenen utama dalam penentuan sikap yaitu kepercayaan, ide ataupun konsep terhadap suatu objek, kehidupan emosional serta kecenderungan untuk bertindak (Notoatmodjo, 2011).

Penelitian ini sejalan dengan penelitian yang dilakukan oleh Wijayanti (2015) yang menyatakan bahwa jumlah subjek yang memiliki sikap sedang adalah seimbang, yaitu subjek untuk sikap baik $(50,7 \%)$ dan subjek untuk sikap sedang $(49,3 \%)$, serta tidak ditemukan subjek yang memiliki sikap kurang, tetapi hasil penelitian ini tidak sejalan dengan penelitian yang dilakukan pada petugas kebersihan di Riau yang menyatakan bahwa sebagian besar subjek penelitian memiliki sikap yang negatif $(56,4 \%)$ terhadap penggunaan 


\begin{tabular}{l|r|r}
\hline \multirow{2}{*}{ Jurnal Penelitian Kesmasy } & Vol. 2 No. 1 & Edition: May-October 2019 \\
\hline \multirow{2}{*}{ Received: 15 October 2019} & http://ejournal.delihusada.ac.id/index.php/JPKSY & Accepted: 25 October 2019 \\
\cline { 2 - 3 } & Revised: 12 October 2019 & \\
\hline
\end{tabular}

APD. Hasil yang berbeda ini dapat disebabkan oleh karakteristik responden yang berbeda.

Berdasarkan data statistik menunjukkan untuk perilaku responden didapatkan hasil bahwa sebagian besar petugas pengangkut sampah memiliki perilaku baik yaitu sebanyak $67.7 \%$ sedangkan dengan perilaku kurang sebanyak $32.3 \%$. Perilaku merupakan suatu aktivitas atau kegiatan organisme yang merupakan hasil interaksi antara perangsang (stimulus) dengan tanggapan dan respon. Perilaku ada yang dapat diamati secara langsung dan juga ada yang tidak dapat diamati secara langsung. Ada banyak faktor yang mempengaruhi perilaku seseorang (Notoatmodjo, 2010), dapat berupa faktor yang berasal dari dalam diri seseorang itu sendiri (faktor internal) maupun yang berasal dari luar (faktor eksternal). Penelitian ini tidak sejalan dengan penelitian yang dilakukan oleh Tombili (2010) yang menyatakan bahwa tindakan tentang penggunaan alat pelindung diri (APD) oleh petugas pengumpul sampah Dinas Kebersihan Kota Kendari sebagian besar masih kurang. Tindakan petugas pengumpul sampah sangat dipengaruhi oleh kebijakan Dinas Kebersihan Kota Kendari baik dalam hal pengawasan maupun pengadaan APD.

Berdasarkan data statistik menunjukkan bahwa ada hubungan antara pengetahuan dengan keselamatan kesehatan kerja yaitu dengan nilai P- Value $0.04<0.05$. Ini menunjukkan bahwa pengetahuan dapat memberi keyakinan untuk berperilaku. Dari hasil penelitian ini menunjukkan bahwa pengetahuan tentang keselamatan kesehatan kerja oleh petugas keselamatan kesehatan kerja oleh petugas pengangkut sampah di Pasir Pengaraian sebagian besar baik. Akan tetapi pada responden yang memiliki pengetahuan yang baik, bisa juga memiliki praktik yang buruk dalam hal keselamatan kesehatan kerja. Hal ini dapat disebabkan karena mereka belum memiliki sikap yang positif terhadap keselamatan kesehatan kerja. Hal ini dapat disebabkan karena frekuensi penyuluhan maupun sosialisasi tentang keselamatan kesehatan kerja masih rendah. Berkaitan dengan pengetahuan untuk mencegah dan mengurangi risiko kecelakaan kerja, Dinas Lingkungan Hidup kabupaten Rokan Hulu sebaiknya menyelenggarakan pelatihan tentang keselamatan kesehatan kerja dan pemberian bantuan alat pelindung diri yang memadai, sehingga dapat digunakan dan selalu dijaga kebersihannya seperti sarung tangan, sepatu bots dan masker (Notoatmodjo, 2011; Sari, 2016b).

Penelitian ini sejalan dengan penelitian yang dilakukan oleh Sari (2016b) bahwa ada hubungan pengetahuan petugas penyapu jalan dalam pemakaian APD saat bekerja. Hasil analisis lanjut menunjukkan peluang petugas penyapu jalan yang memiliki pengetahuan rendah tentang pemakaian APD beresiko sebanyak 1,340 kali menerapkan pemakaian APD yang buruk dari pada petugas penyapu jalan yang memiliki pengetahuan yang tinggi tentang pemakaian APD (dengan OR: 1,340; dan $\mathrm{CI} 0,538 ; 3,336)$.

Berdasarkan data statistik menunjukkan bahwa ada hubungan antara sikap dengan keselamatan kesehatan kerja yaitu dengan nilai P $0.026<0.05$. Ini menggambarkan bahwa sikap merupakan reaksi atau respon yang masih tertutup dari seseorang terhadap suatu stimulus atau objek. Sebagai suatu reaksi maka sikap berhubungan dengan dua hal (Notoatmodjo, 2011) yaitu suka dan setuju yang membawa pada sikap positif (favourabe) dan tidak sukadan tidak setuju atau sikap negatif (unfavourabe). Dari hasil penelitian ini menunjukkan bahwa sikap tentang keselamatan kesehatan kerja oleh petugas pengangkut sampah di PasirPengaraian baik. Akan tetapi responden yang memiliki sikap yang positif, bisa juga memiliki praktik yang buruk dalam hal keselamatan kesehatan kerjanya (Notoatmodjo, 2010).

Hal ini dapat disebabkan karena kurangnya pengetahuan responden tentang keselamatan kesehatan kerja dan tidak adanya keyakinan terhadap fungsi alat pelindung diri. Selain itu juga karena kurangnya pengawasan dari atasan, tidak adanya sanksi yang kuat dan tenaga kerja merasa tidak nyaman memakai alat pelindung diri. Secara operasional sikap dapat diekspresikan dalam bentuk kata-kata atau tindakan yang merupakan respon atau reaksi dari sikapnya terhadap objek tertentu, baik yang berupa orang, peristiwa, situasi dan lain sebagainya. Sebagai suatu reaksi maka sikap berhubungan dengan dua hal yaitu suka, setuju yang membawa pada sikap positif (favourable) dan tidak suka, tidak setuju atau sikap negatif (unfavourable). 


\begin{tabular}{l|r|r}
\hline Jurnal Penelitian Kesmasy & Vol. 2 No. 1 & Edition: May - October 2019 \\
\hline \multirow{2}{*}{ Received: 15 October 2019} & http://ejournal.delihusada.ac.id/index.php/JPKSY & Accepted: 25 October 2019 \\
\cline { 2 - 3 } & Revised: 12 October 2019 & \\
\hline
\end{tabular}

Dalam sikap positif, kecenderungan tindakan adalah mendekati menyenangi, mengharapkan obyek tertentu. Sedangkan dalam sikap negatif terdapat kecenderungan untuk menjauhi, menghindari, membenci, tidak menyukai obyek tertentu, sikap yang ada pada diri seseorang dapat dipengaruhi oleh faktor internal, yaitu faktor fisiologis dan psikologis, serta faktor eksternal. Faktor eksternal dapat berwujud situasi yang dihadapi oleh individu, normanorma yang ada dalam masyarakat, hambatanhambatan atau pendorong-pendorong yang ada dalam masyarakat. Hal ini dapat mempengaruhi seseorang dalam berperilaku (Notoatmodjo, 2010).

Penelitian ini sejalan dengan penelitian yang dilakukan oleh Rahayu (2015) bahwa terdapat hubungan yang bermakna antara sikap dengan penerapan manajemen budaya K3 setelah mendapatkan hasil uji statistik nilai Odd Ratio sebesar 9,286 (pada 95\% CI = 3,250-26,531) artinya responden yang mempunyai sikap tidak baik memiliki resiko 9,286 kali tidak menerapkan manajemen budaya K3 dibandingkan responden yang mempunyai sikap baik.

Terkait hubungan antara perilaku dengan keselamatan kesehatan kerja diperoleh nilai $P$ $0.034<0.005$ yang menunjukkan bahwa terdapat hubungan antara perilaku dengan keselamatan kesehatan kerja. Hasil ini sejalan dengan penelitian yang dilakukan oleh Tombili (2010) yang menyatakan bahwa sebagian besar pemulung yang berada di TPA Kedaung Wetan Tangerang memiliki perilaku penggunaan APD dengan ketegori kurang baik, yaitu sebanyak 30 orang $(45,45 \%)$, dimana para pemulung tersebut menggunakan APD yang tidak lengkap pada saat bekerja. Pemulung yang memiliki perilaku kurang baik terhadap penggunaan APD memiliki sikap dan tindakan yang negatif terhadap penggunaan $A P D$, seperti tidak merasa perlu menggunakan $A P D$, tidak merasa nyaman menggunakan APD, tidak merasa penting menggunakan APD, bosan menggunakan APD, merasa terganggu menggunakan APD, tidak menggunakan sarung tangan, tidak menggunakan sepatu boot, tidak menggunakan masker, dan tidak menggunakan baju pelindung saat bekerja.

\section{KESIMPULAN}

Berdasarkan hasil penelitian disimpulkan halhal sebagai berikut:
1. Dari hasil penelitian yang telah dilakukan terkait hubungan antara pengetahuan pengangkut sampah terhadap aspek keselamatan kesehatan kerja dalam pengolahan sampah di TPS di Pasir Pengaraian Rokan hulu Riau didapati nilai p $0.04<0.05$ yang berarti bahwa ada hubungan yang signifikan antara pengetahuan responden terhadap aspek keselamatan kesehatan kerja.

2. Dari hasil penelitian yang telah dilakukan terkait hubungan antara sikap pengangkut sampah terhadap aspek keselamatan kesehatan kerja dalam pengolahan sampah di TPS di Pasir Pengaraian Rokan hulu Riau didapati nilai p $0.026<0.05$ yang berarti ada hubungan yang signifikan antara sikap terhadap aspek keselamatan kesehatan kerja.

3. Dari hasil penelitian yang telah dilakukan terkait hubungan antara perilaku pengangkut sampah terhadap aspek keselamatan kesehatan kerja dalam pengolahan sampah di TPS di Pasir Pengaraian Rokan hulu Riau didapati nilai p $0.034<0.05$ yang berarti ada hubungan yang signifikan antara perilaku terhadap aspek keselamatan kesehatan kerja.

\section{DAFTAR PUSTAKA}

Badan Pusat Statistik Provinsi Riau. 2016. Jumlah Penduduk Provinsi Riau Menurut Jenis Kelamin dan Kabupaten/Kota. Available from: https://riau.bps.go.id/linkTabelStatis/vie $\underline{w} / \mathrm{id} / 233$

Irwanto (2002). Psikologi Umum (Buku Panduan Mahasiswa). Jakarta: PT Prenhallindo.

Notoatmodjo, S. 2010. I/mu Perilaku Kesehatan. Jakarta: Rineka Cipta.

Notoatmodjo, S. 2011. Kesehatan Masyarakat IImu \& Seni. Jakarta: Rineka Cipta.

Notoatmodjo, S. 2012. Metodologi Penelitian Kesehatan. Jakarta: Rineka Cipta.

Rahayu, E.P. 2015. Hubungan Antara Pengetahuan, Sikap, dan Perilaku Karyawan dengan Penerapan Manajemen Budaya Keselamatan dan Kesehatan Kerja. STIKES Hang Tuah. 


\begin{tabular}{l|c|c}
\hline \multirow{2}{*}{ Jurnal Penelitian Kesmasy } & Vol. 2 No. 1 & Edition: May-October 2019 \\
\hline \multirow{2}{*}{ Received: 15 October 2019} & http://ejournal.delihusada.ac.id/index.php/JPKSY & Accepted: 25 October 2019 \\
\cline { 2 - 3 } & Revised: 12 October 2019 & \\
\hline
\end{tabular}

Rahmi, A., \& Rusmaini. 2013. Evaluasi Sistem Transportasi Sampah di Kabupaten Rokan Hulu, Universitas Pasir Pengaraian.

Redjeki, S. 2016. Kesehatan dan Keselamatan Kerja. Kementerian Kesehatan Republik Indonesia.

Sari et.al. 2016a. Gambaran Pengetahuan pemulung Terhadap Aspek Keselamatan Kesehatan Kerja (K3) dalam Pengolahan Sampah di Tempat Pembuangan Sementara Kota Pekan Baru. Universitas Riau.

Sari et.al. 2016b. Hubungan Pengetahuan dan Sikap penyapu Jalan dalam Pemakaian Alat Pelindung Diri (APD). Universitas Riau.

Suma'mur. 2013. Higiene Perusahaan dan Kesetahan Kerja (HIPERKES). Jakarta: Hal 462-466.

Tombili, A., \& Mardewi, R. 2010. Studi Pengetahuan, Sikap dan Tindakan tentang Alat Pelindung Diri pada Petugas Pengumpul Sampah di Dinas Kebersihan Kota kendari. STIK Avicenna.

Wijayanti, Dina Fitri. 2015. Hubungan Pengetahuan, Sikap dan Tindakan Penggunaan Alat Pelindung Diri terhadap Keluhan Gangguan Kulit pada Petugas Sampah TPA Batu Layang Pontianak. Jurnal Mahasiswa Fakultas Kedokteran Untan, 2015. 